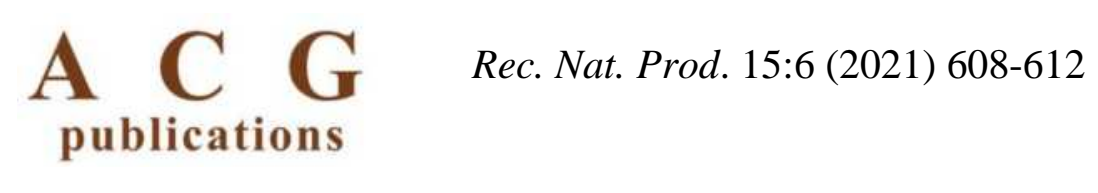

records of natural products

\title{
Bioactive Natural Products from Endophytic Fungus Aspergillus nidulans Associated with Nyctanthes arbor-tristis Linn.
}

\author{
Talea Sana $\oplus^{1}$, Bina S. Siddiqui $\oplus^{1, *}$, Majid Khan $\oplus^{1}$, Saleem Shahzad $\oplus^{2}$, \\ Samia Sattar $\oplus^{2}$ and Sabira Begum $\oplus^{1}$
}

${ }^{l}$ HEJ Research Institute of Chemistry, International Center for Chemical and Biological Sciences, University of Karachi, Karachi-75270, Pakistan

${ }^{2}$ Department of Agriculture \& Agribusiness Management, University of Karachi, Karachi-75270, Pakistan

(Received March 01, 2021; Revised May 06, 2021; Accepted May 08, 2021)

\begin{abstract}
Endophytic fungi are a substantial source of bioactive secondary metabolites. Present studies on Aspergillus nidulans - an endophytic fungus from Nyctanthes arbor-tristis Linn. afforded one new 1, 5-dihydroxy3-methylxanthone-6-carboxylic acid methyl ester (1) and one known 5, 10-dihydro-phenazine-1-carboxylic acid (2) compound. The structures were elucidated by spectral techniques (Mass, 1D and 2D NMR), and their urease, carbonic anhydrase and prolyl endopeptidase inhibitory activities were evaluated. Compound 1 showed notable prolyl endopeptidase inhibition $\left(\mathrm{IC}_{50}=3.13 \pm 0.09 \mu \mathrm{M}\right)$ and compound 2 showed significant carbonic anhydrase $\left(\mathrm{IC}_{50}=14.3 \pm 1.05 \mu \mathrm{M}\right)$ and urease $\left(\mathrm{IC}_{50}=24.3 \pm 1.15 \mu \mathrm{M}\right)$ inhibition.
\end{abstract}

Keywords: Aspergillus nidulans; Nyctanthes arbor-tristis; xanthone. (C) 2021 ACG Publications. All rights reserved.

\section{Plant and Fungal Source}

The endophytic fungus was isolated by incubating the surface sterilized segments [1] of apparently healthy looking leaves of $N$. arbor-tristis collected from University of Karachi campus and identified by the Taxonomist Dr. Afsheen, Department of Botany, University of Karachi. A voucher specimen (G.H. No. 93294) has been deposited in the Herbarium of the same department. The fungal isolate used in the present studies was identified as Aspergillus nidulans based on cultural and morphological characters [2]. The isolate was deposited at the Karachi University Culture Collection where its accession number is 89 .

\section{Previous Studies}

Endophytic fungi are a continuing source of new secondary metabolites and have a great impact on modern medicines [3]. Hence the present study was undertaken on Aspergillus nidulans-an endophytic

\footnotetext{
"Corresponding author:E-Mail: siddiqui_bina@yahoo.com
} 
fungus from Nyctanthes arbor-tristis Linn (Native name: night jasmine; Family: Oleaceae), known as 'the tree of sorrow' by native people of Indo-Pak subcontinent and used in Ayurveda, Siddha, and Unani systems of medicines for treating distinct diseases [4]. Many traditional uses are attributed to this tree which led to isolation of several bioactive chemical constituents from different parts of the plant including anti-allergic [5], anti-cancer [6], anti-diabetic [7], anti-malarial [8], and anti-microbial activity [9, 10]. These reports prompted us to explore the fungus from this tree with reference to the chemistry and biological activities of its constituents. As a result, two compounds, one new, 1, 5-dihydroxy-3methylxanthone-6-carboxylic acid methyl ester (1) and one known 5, 10-dihydro-phenazine-1-carboxylic acid (2) were isolated and their structures elucidated. Their urease, carbonic anhydrase and prolyl endopeptidase inhibitory activities were determined.

\section{Present Study}

The endophytic fungi were isolated by incubating the surface sterilized segments of healthy leaves of N. arbor-tristis Linn. on Potato Dextrose agar, malt extract agar and Czapek Dox agar. Thirteen species of fungi were isolated. Aspergillus nidulans was selected for present studies. It grew well on all the three media so for mass culturing only potato dextrose broth was used. The selected fungus was inoculated in potato dextrose broth in one liter Erlenmeyer flasks each containing $200 \mathrm{~mL}$ broth. The flasks were incubated in a cool incubator at $28^{\circ} \mathrm{C}$ for two days to initiate the mycelial growth. These flasks were incubated in a shaking incubator at $28^{\circ} \mathrm{C}$ for four weeks to facilitate submerged mycelial growth. The fermented cultures were then filtered through two-folds of sterile cheese cloth to get the fungal biomass. The broth $(9.0 \mathrm{~L})$ was extracted with ethyl acetate $(5 \times 10 \mathrm{~L})$ at room temperature. The ethyl acetate extracts were combined, dried (anhyd. $\mathrm{Na}_{2} \mathrm{SO}_{4}$ ) and concentrated to yield a gummy extract $(0.8984 \mathrm{~g})$.

The ethyl acetate extract $(0.8984 \mathrm{~g})$ was subjected to column chromatography and eluted with petroleum ether-acetone in increasing order of polarity to obtain two major ( $F r .1$ and $F r .2)$ and several small fractions. Fr.1 eluted with petroleum ether-acetone (9.9-0.1) and afforded a pure compound identified as 5, 10-dihydrophenazine-1-carboxylic acid (2; $9.0 \mathrm{mg})$ reported earlier by our group [11]. $\mathrm{Fr}$. 2 eluted with petroleum ether-acetone (9.8-0.2) and purified using recycling HPLC; mobile phase hexaneethyl acetate (8.6:1.4); flow rate $(3 \mathrm{~mL} / \mathrm{min})$ to afford a new compound 1, 5-dihydroxy-3methylxanthone-6-carboxylic acid methyl ester (1; $5.0 \mathrm{mg}$; retention time $38 \mathrm{mins})$.

1, 5-dihydroxy-3-methylxanthone-6-carboxylic acid methyl ester (1): Yellow amorphous powder; UV $\left(\mathrm{CHCl}_{3}\right) \lambda_{\max }: 238,307,351 \mathrm{~nm}$; IR $v_{\max }\left(\mathrm{CHCl}_{3}\right): 3300-2600,1680,1640 \mathrm{~cm}^{-1} ;{ }^{1} \mathrm{H}$ and ${ }^{13} \mathrm{C}$ NMR data, see Table 1; EIMS (rel. int.): m/z 300 (20), 268 (100), 240 (17), 212 (5), 184 (3), 155 (2), 128 (3), 106 (1), 77 (1); HR-EIMS: $m / z 300.0637$ (calcd. 300.0630 for $\mathrm{C}_{16} \mathrm{H}_{12} \mathrm{O}_{6}$ ).

Table 1. ${ }^{1} \mathrm{H}(400 \mathrm{MHz})$ and ${ }^{13} \mathrm{C}-\mathrm{NMR}(150 \mathrm{MHz})$ Data of 1 in $\mathrm{CDCl}_{3}(\delta$ in ppm)

\begin{tabular}{llllll}
\hline & & \multicolumn{1}{c}{$\mathbf{1}$} & \\
\hline No. & $\boldsymbol{\delta}_{\mathbf{H}}$ (mult., $\boldsymbol{J}$ in Hz) & $\boldsymbol{\delta}_{\mathbf{C}}$ & No. & $\boldsymbol{\delta}_{\mathbf{H}}$ (mult., $\boldsymbol{J}$ in Hz) & $\boldsymbol{\delta}_{\mathbf{C}}$ \\
\hline 1 & & $161.1, \mathrm{C}$ & 6 & & $118.6, \mathrm{C}$ \\
$1-\mathrm{OH}$ & $12.17, \mathrm{~s}$ & & 7 & $7.33, \mathrm{~d}(9.2)$ & $125.4, \mathrm{CH}$ \\
$1^{\prime}$ & & $107.8, \mathrm{C}$ & 8 & $7.45, \mathrm{~d}(9.2)$ & $122.3, \mathrm{CH}$ \\
2 & $6.61, \mathrm{~d}(1.2)$ & $111.4, \mathrm{CH}$ & $8^{\prime}$ & & $113.6, \mathrm{C}$ \\
3 & & $148.8, \mathrm{C}$ & 9 & & $180.1, \mathrm{C}$ \\
4 & $6.72, \mathrm{~d}(1.2)$ & $107.2, \mathrm{CH}$ & 11 & $2.41, \mathrm{~s}$ & $22.6, \mathrm{CH}_{3}$ \\
$4^{\prime}$ & & $155.6, \mathrm{C}$ & 12 & & 169.1 \\
5 & & $150.8, \mathrm{C}$ & 13 & $3.98, \mathrm{~s}$ & $53.1, \mathrm{OCH}_{3}$ \\
$5^{\prime}$ & & $152.3, \mathrm{C}$ & & & \\
\hline
\end{tabular}

The HR-EIMS of $\mathbf{1}$ showed exact $\mathbf{M}^{+}$at $\mathrm{m} / z 300.0637$ corresponding to the molecular formula $\mathrm{C}_{16} \mathrm{H}_{12} \mathrm{O}_{6}$, indicating eleven degrees of unsaturation. The ${ }^{1} \mathrm{H}-\mathrm{NMR}$ spectrum (Table 1) displayed a 
A new xanthone via endophytic fungus

hydrogen bonded proton $\left(\delta_{\mathrm{H}} 12.17(1 \mathrm{H}, \mathrm{s})\right.$, two ortho coupled aromatic protons at $\delta_{\mathrm{H}} 7.45(1 \mathrm{H}, \mathrm{d}, J=9.2$ $\mathrm{Hz}, \mathrm{H}-8)$ and $\delta_{\mathrm{H}} 7.33(1 \mathrm{H}, \mathrm{d}, J=9.2 \mathrm{~Hz}, \mathrm{H}-7)$, a pair of meta coupled protons at $\delta_{\mathrm{H}} 6.72(1 \mathrm{H}, \mathrm{d}, J=1.2$ $\mathrm{Hz}, \mathrm{H}-4)$ and $\delta_{\mathrm{H}} 6.61(1 \mathrm{H}, \mathrm{d}, J=1.2 \mathrm{~Hz}, \mathrm{H}-2)$, two sp ${ }^{3}$ methyl groups $\delta_{\mathrm{H}} 3.98\left(3 \mathrm{H}, \mathrm{s}, \mathrm{OC}_{3}\right), 2.41(3 \mathrm{H}, \mathrm{s}$, $\mathrm{C}_{3}$ ). The ${ }^{13} \mathrm{C}-\mathrm{NMR}$ broad band spectrum showed 16 signals, out of which $2 \mathrm{CH}_{3}$ (1 methyl and 1 methoxy) and $4 \mathrm{CH}$ carbons were recognized with the help of DEPT-135 and DEPT-90 spectra. The remaining carbons were due to 10 quaternary carbons, including 8 aromatic, 1 ketone and 1 carboxylic acid methyl ester carbon (Table 1).

These data and the key HMBC correlations (Figure 1) from $\mathrm{OH}$ to $\mathrm{C}-1 / \mathrm{C}-1$ '/ C-2; from $\mathrm{H}-7$ to $\mathrm{C}$ 12/ C-8'/ C-5; from H-8 to C-7/ C-6/ C-5'/ C-9; from H-11 to C-2/ C-3/C-4; from H-13 to C-12; from H-4 to $\mathrm{C}-1$ '/ C-4'/ C-2/ C-11; from $\mathrm{H}-2$ to $\mathrm{C}-1 / \mathrm{C}-4 / \mathrm{C}-11$ established the planar structure of 1 as 1, 5dihydroxy-3-methylxanthone-6-carboxylic acid methyl ester.

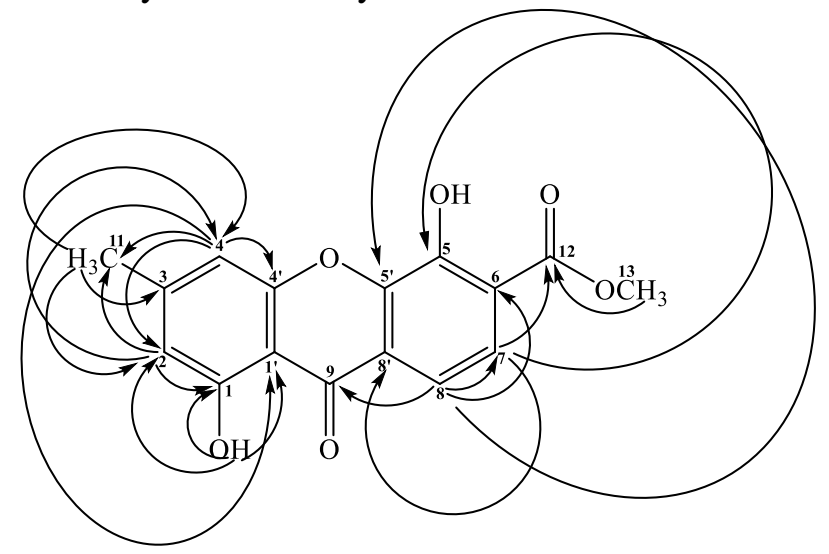

Figure 1. Structure of compound 1 and important HMBC correlations

Enzymes Inhibition Assays: Enzymes in the biological system play multiple harmful roles leading to several diseases. Hence studies on enzyme inhibitors both natural and synthetic origins have attracted much attention in recent years. Hence in the present study urease, carbonic anhydrase and prolyl endopeptidase inhibition activities of the isolated compounds were determined. These enzyme inhibition activities support the attributed biological/medicinal properties of the plant and its various parts including activities related to digestive system, CNS and ulcerogenic activities $[12,13]$.

Urease Inhibitory Assay: Urease inhibitors have recently attracted much attention as potential new antiulcer drugs. Although certain synthetic classes of compounds like hydroxamic acids, imidazoles and phosphazenes have shown potential urease inhibition. However, very limited studies have been done so far on natural products with urease inhibitory activity. So, there is a need to search for inhibitors of urease from natural resources. The urease inhibition assay was performed spectrophotometrically. The enzyme reaction mixture; comprised of, $25 \mu \mathrm{L}$ of urease solution (1 U/well) was incubated with $5 \mu \mathrm{L}$ of test compound $(250 \mu \mathrm{M})$ for 15 minutes, at $30{ }^{\circ} \mathrm{C}$. Thereafter, $55 \mu \mathrm{L}$ of urea (substrate) with concentration of $100 \mathrm{mM}$ was added and the plate was again incubated for $15 \mathrm{~min}$ at $30^{\circ} \mathrm{C}$. After incubation, $45 \mu \mathrm{L}$ of phenol reagents ( $1 \% \mathrm{w} / \mathrm{v}$ phenol and $0.005 \% \mathrm{w} / \mathrm{v}$ sodium nitroprusside), and $70 \mu \mathrm{L}$ of alkali reagents $(0.5 \% \mathrm{w} / \mathrm{v}$ sodium hydroxide and $0.1 \%$ sodium hypochlorite) were added to each well. The plate was again incubated for $50 \mathrm{~min}$ at $30{ }^{\circ} \mathrm{C}$. Activity of urease was monitored with the rate of production of ammonia continuously following the method of Weatherburn, [14] and change in absorbance was monitored at $630 \mathrm{~nm}$ on a ELISA plate reader (Spectra Max M2, Molecular Devices, CA, USA). Acetohydroxamic acid was used as a standard compound.

Carbonic Anhydrase Assay: Carbonic anhydrase inhibitors are used for the treatment of glaucoma, edema, and epilepsy. Several isoforms of this enzyme exist in the biological system. Yet none of the natural inhibitor is reported for this enzyme. So, in the light of these urgencies we evaluated our compounds against these enzymes and noteworthy results have been obtained. The spectrophotometric carbonic anhydrase inhibitory assay was carried by following the standard protocol reported by Pocker 
and Meany [15]. First the $140 \mu \mathrm{L}$ of the HEPES-tris buffer (pH 7.4, $20 \mathrm{mM}$ ), $20 \mu \mathrm{L}$ of test compounds $(0.5 \mathrm{mM})$ prepared in DMSO and $20 \mu \mathrm{L}$ of purified bovine erythrocyte CA-II enzyme $(0.1 \mathrm{mg} / \mathrm{mL})$ was added to the 96 well plates. The plate was kept in incubation for a duration of 15 minutes. Soon after the incubation the $20 \mu \mathrm{L}$ of 4-nitrophenyl acetate substrate $(0.7 \mathrm{mM})$ was added to the reaction mixture and again the plat was kept in micro plate readers (Bio-Rad, Molecular Devices, CA, USA). The continuous increase in the product formation was thoroughly monitored with one-minute interval for 30 minutes at 25 ${ }^{\circ} \mathrm{C}$. The obtained results were then processed on Grafit 7 (Erithacus Software). For the $\mathrm{IC}_{50}$ calculation EZ-FIT software was used (Perrella Scientific Inc).

Prolyl Endopeptidase (PEP) Assay: PEP plays an important role on central nervous system. Low molecular weight inhibitors of Prolyl endopeptidase (PEP) have been reported in the literature but the majority of these are synthetic. Most of the natural PEP inhibitors isolated have been of microbial origin while PEP inhibitors from plants have rarely been investigated. Spectrophotometric assay for prolyl endopeptidase inhibitory activity was performed by following the protocol Yoshimoto et al. [16] with slight meaningful modifications. Briefly, in a total of $200 \mu \mathrm{L}$ reaction volume, $140 \mu \mathrm{L}$ of sodium phosphate buffer $(50 \mathrm{mM}, \mathrm{pH} 7.0), 20 \mu \mathrm{L}$ of the test compound $(0.5 \mathrm{mM}$ in methanol), and $20 \mu \mathrm{L}$ of prolyl endopeptidase solution ( $0.02 \mathrm{U} /$ well) were added into 96 -well plate. Negative control contained 20 $\mu \mathrm{L}$ methanol $\left(\mathrm{CH}_{3} \mathrm{OH}\right)$ instead of the test compound, while Z-Pro-prolinal $(0.5 \mathrm{mM})$ was used as the positive control. The reaction mixture was incubated at $30{ }^{\circ} \mathrm{C}$ for 10 min after which a pre-read was taken at $410 \mathrm{~nm}$. Now $20 \mu \mathrm{L}$ of substrate solution, i.e., Z-Gly-Pro-4-nitroanilide ( $0.4 \mathrm{mM}$ in 1, 4-dioxane) was added, and change in absorbance was recorded continuously at $410 \mathrm{~nm}$ for $30 \mathrm{~min}$, using a 96-well plate reader (SpectraMax-384, Molecular Devices, CA, USA). The final concentration of methanol and 1, 4dioxane were $10 \% \mathrm{v} / \mathrm{v}$ in the reaction mixture. All reactions were performed in triplicates in 96-well microplate and results are mention as mean of the triplicate experiment.

In this study, the urease, carbonic anhydrase and prolyl endopeptidase inhibition activities of the compounds 1 and 2 from Aspergillus nidulans-an endophytic fungus from N. arbor-tristis Linn. were evaluated and the results are presented in Table 2. In urease inhibition assay, compound $\mathbf{2}$ showed remarkable urease inhibition with $\mathrm{IC}_{50}(24.3 \pm 1.15 \mu \mathrm{M})$. Compound 1 showed moderate inhibition with $\mathrm{IC}_{50} 41.2 \pm 0.98 \mu \mathrm{M}$ (acetohydroxamic acid (standard) $\mathrm{IC}_{50}=19.6 \pm 0.34 \mu \mathrm{M}$ ). In carbonic anhydrase inhibition assay, compound 2 exhibited potent inhibition with $\mathrm{IC}_{50}=14.3 \pm 1.05 \mu \mathrm{M}$ as compared to standard acetazolamide $\left(\mathrm{IC}_{50}=18.2 \pm 1.43 \mu \mathrm{M}\right)$. Compound 1 showed good inhibition with $\mathrm{IC}_{50}=36.3 \pm$ $1.90 \mu \mathrm{M}$. In the prolyl endopeptidase inhibition assay, compound 1 showed significant inhibition with $\mathrm{IC}_{50}=3.13 \pm 0.09 \mu \mathrm{M}$ as compared to standard Z-prolyl-prolinal $\left(\mathrm{IC}_{50}=0.00265 \pm 0.01 \mu \mathrm{M}\right)$. Compound 2 showed relatively weak inhibition $\left(\mathrm{IC}_{50}=11.3 \pm 1.00 \mu \mathrm{M}\right)$.

Table 2. Urease, carbonic anhydrase and prolyl endopeptidase inhibition activities of compounds $\mathbf{1}$ and $\mathbf{2}$

\begin{tabular}{|c|c|c|c|c|c|c|}
\hline \multicolumn{3}{|c|}{ Urease } & \multicolumn{2}{|c|}{ Carbonic anhydrase } & \multicolumn{2}{|c|}{ Prolyl endopeptidase } \\
\hline Compounds & $\begin{array}{c}\% \\
\text { inhibition }\end{array}$ & $\begin{array}{c}\mathrm{IC}_{50} \pm \text { S.E.M } \\
(\mu \mathrm{M})^{\mathrm{a}}\end{array}$ & $\begin{array}{c}\% \\
\text { inhibition }\end{array}$ & $\begin{array}{c}\mathrm{IC}_{50} \pm \text { S.E.M } \\
(\mu \mathrm{M})^{\mathrm{a}}\end{array}$ & $\begin{array}{c}\% \\
\text { inhibition }\end{array}$ & $\begin{array}{c}\mathrm{IC}_{50} \pm \text { S.E.M } \\
(\mu \mathrm{M})^{\mathrm{a}}\end{array}$ \\
\hline 1 & 81.2 & $41.2 \pm 0.98$ & 87.6 & $36.3 \pm 1.90$ & 97.6 & $3.13 \pm 0.09$ \\
\hline 2 & 79.5 & $24.3 \pm 1.15$ & 98.1 & $14.3 \pm 1.05$ & 93.1 & $11.3 \pm 1.00$ \\
\hline Standard ${ }^{\mathrm{b}}$ & 94.6 & $19.6 \pm 0.34$ & 88.4 & $18.2 \pm 1.43$ & 87.4 & $0.00265 \pm 0.01$ \\
\hline
\end{tabular}

Concentration of each compound and standard were $0.5 \mathrm{mM}$

${ }^{a}$ S.E.M. = Standard Error Mean

bStandard for urease, carbonic anhydrase and prolyl endopeptidase activities are acetohydroxamic acid, acetazolamide and z-prolyl-prolinal respectively.

Present results on the secondary metabolites and biological activities of Aspergillus nidulans-an endophytic fungus from Nyctanthes arbor-tristis, emphasize the significance of study in this area and suggest that further organisms need to be explored in order to obtain potential medicinal agents. 
A new xanthone via endophytic fungus

\section{Acknowledgment}

The study was supported by the Pakistan Academy of Sciences by the grant \# 5-9/PAS/52

\section{Supporting Information}

Supporting Information accompanies this paper on http://www.acgpubs.org/journal/records-ofnatural-products

\section{ORCID}

Talea Sana: 0000-0002-4239-8577

Bina S. Siddiqui: 0000-0001-8160-0021

Majid Khan: 0000-0002-9287-2046

Saleem Shahzad: 0000-0001-5316-8921

Samia Sattar: 0000-0002-6806-4081

Sabira Begum: 0000-0002-1173-2413

\section{References}

[1] J. K. Dobranic, J. A., Johnson and Q. R. Alikhan (1995) Isolation of endophytic fungi from eastern larch (Larix laricina) leaves from New Brunswick, Canada, Can. J. Microbiol. 41, 194-198.

[2] K. B. Raper and D. I. Fennell (1965). The Genus Aspergillus. Williams \& Williams, Baltimore.

[3] J. S. Cruz, C. A. da Silva and L. Hamerski (2020). Natural products from endophytic fungi associated with Rubiaceae species, J. Fungi 6, 128 (26 pages).

[4] S. Das, D. Sasmal and S. P. Basu (2008). Anti-inflammatory and antinociceptive activity of Arbortristoside- A, J. Ethnopharm, 116, 198-203.

[5] P. P. Gupta, R. C. Srimal and J.S. Tandon (1993). Anti-allergic activity of some traditional Indian medicinal plants, Int. J. Pharmacog. 31, 15-18.

[6] T. Susan, A. Muzaffer and K. K. Purushothaman (1986). Inhibitory activity of arbortristoside A in fibrosarcoma in albino rats, Arogya 12, 122-130.

[7] V. Sharma, Pooja and A. Marwaha (2011). Hypoglycemic activity of methanolic extracts of Nyctanthes arbor-tristis Linn. root in alloxan induced diabetic rats, Int. J. Pharm. Pharm. Sci. 3, 210-212.

[8] R. D. Aminuddin, A. Girach and S. Khan (1993). Treatment of malaria through herbal drugs from Orissa, India, Fitoterapia 64, 545-548.

[9] M. P. Darokar, A. Mathur, S. Dwivedi, R. Bhalla, S. P. S. Khanuja and S. Kumar (1998). Detection of antibacterial activity in the floral petals of some higher plants, Curr. Sci. 75, 187-189.

[10] N. A. Khatune, M. A. Mosaddik and M. E. Haque (2001). Antibacterial activity and cytotoxicity of Nyctanthes arbor-tristis flowers, Fitoterapia 72, 412-414.

[11] T. Sana, B. S. Siddiqui, S. Shahzad, A. D. Farooq, F. Siddiqui, S. Sattar and S. Begum (2019). Antiproliferative activity and characterization of metabolites of Aspergillus nidulans: An endophytic fungus from Nyctanthes arbor-tristis Linn. against three human cell lines, Med. Chem. 15, 352-359.

[12] R.S. Saxena, B. Gupta and S. Lata (2002). Tranquilizing, antihistaminic and purgative activity of Nyctanthes arbor-tristis leaf extract, J. Ethanopharmocol. 81, 321-325.

[13] R.S. Saxena, B. Gupta, K.K. Saxena, V.K. Srivastava and D.N. Prasad (1987). Analgesic, antipyretic and ulcerogenic activity of Nyctanthes arbor-tristis leaf extract, J. Ethanopharmacol. 19, 193-200.

[14] M. W. Weatherburn (1967). Phenol-hypochlorite reaction for determination of ammonia, Anal. Chem. 39, 971-974.

[15] Y. Pocker and J. E. Meany (1967). The catalytic versatility of erythrocyte carbonic anhydrase. II. Kinetic studies of the enzyme-catalyzed hydration of pyridine aldehydes, Biochemistry 6, 239-246.

[16] T. Yoshimoto, A. K. Sattar, W. Hirose and D. Tsuru (1988). Studies on prolyl endopeptidase from shakashimeji (Lyophyllum cinerascens): Purification and enzymatic properties, J. Biochem. 104, 622-627.

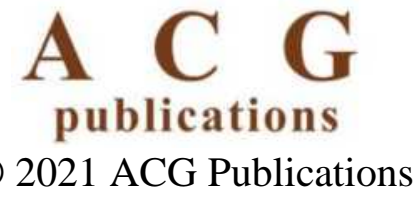

